\title{
ФАКТОРИ, ЯКІ СПРИЧИНЯЮТЬ ЗАПОЗИЧЕННЯ ЛЕКСИЧНИХ ОДИНИЦЬ СФЕРИ ТУРИЗМУ ДО МОВНОГО СТАНДАРТУ
}

Прима В. В. Фактори, які спричиняють запозичення лексичних одиниць сфери туризму до мовного стандарту.

У статті розкрито причини появи нової лексики в мовному стандарті, визначено використання туристичної лексики як основи експресивності. Доведено на прикладах, що в туристичному контексті лексика набуває додаткових відтінків значення.

Ключові слова: побутова лексика, туристична лексика, запозичення.

Прима В. В. Факторы заимствования новых лексических единиц в сфере туризма в языковой стандарт.

В статье раскрываются причины появления новой лексики в языковом стандарте, анализируется использование туристической лексики как основы экспрессивности. На примерах доказано, что в туристическом контексте лексика обретает дополнительные оттенки значения.

Ключевые слова: бытовая лексика, туристическая лексика, заимствования.

Prima V. V. Reasons for borrowing lexical unites of tourism in language standard.

The role of appearance new vocabulary in language standard is determined. The usage of tourism lexicon as the base for expressivity is analyzed. It is proved, that in touristic context lexical unites get new meaning.

Key words: every-day lexic, touristic lexic, borrowings. 
Побутову лексику туризму розглядає така наука, як інтерлінгвокультурологія, що передбачає опис іноземної культури під час безпосереднього міжкультурного спілкування [5, с. 107]. Туризм $\epsilon$ однією зі сфер, де найчіткіше проявляється міжкультурне спілкування. А туристичний путівник - це один із найпоширеніших на сьогодні типів текстів іншомовного спілкування. Під час міжкультурного діалогу, який безпосередньо виникає при контакті представників різних культур, формується спеціалізована мова - мова міжнародного спілкування. Розвиток туризму має свою специфіку, перспективи та потребує наукового обгрунтування. Специфіка сучасного стану туристичного комплексу України полягає в тому, що встановлення української державності визначає процес самостійного розвитку відповідного комплексу, який остаточно формулюється 3 упровадженням нормативів візового режиму в країні. Цей факт сприяє підвищенню туристської рухомості населення, створює умови для дослідження міграційних потоків туристів через кордони держави, а водночас - i виокремлення, обробки та аналізу запозичених іншомовних лексичних одиниць, зокрема - англомовних [4, с. 8-9].

Досліджуючи автентичні путівники по Україні як типи тексту іншомовного опису культури, ми звертаємося до англійської мови міжкультурного спілкування. Українська культура входить у двадцятку найбільш освоєних англійською мовою культур [3].

Традиційно мовознавці виділяють серед побутової лексики назви елементів одягу, взуття, предметів повсякденного вжитку, назви кулінарних страв, грошових одиниць, а також іншу лексику, що використовується в мовленні. Хоч з точки зору теорії міжкультурного спілкування поняття «побутова лексика туризму» має ширший діапазон розуміння. Під побутовою лексикою туризму ми розглядаємо широкий спектр тем, які властиві українській мові, 3 якими обов'язково зіштовхуються туристи, відвідуючи ту чи ту країну. Це передусім готелі (lux, polu-lux, turbaza), суспільний транспорт (marshrutka, providnytsya, gazelka), покупки, гроші (umovni odynytsi, bankomat, hryvnya), кулінарія (zakuski, holubtsi, pampushki, borshch, chicken Kiev, halushki), різноманітні громадські установи, 3 якими час від часу доводиться зустрічатись туристам (shvydka dopomoga, apteka), а також духовний світ українців 3 національними традиціями та святами (dacha, banya, Noviy Rik, Paska, pysanka, vishivanka, rushnik). Прийом тут досить простий - використовується так зване «паралельне підключення», тобто 
утворення мовної одиниці, що передає мовленнєву реалію і iї пояснення. При цьому пояснення використовується тільки при первинному введення лексичної одиниці [2].

Проблема запозичення в англійській мові здавна цікавила філологів і мовознавців. Вивченням цього питання займались відомі мовознавці, як закордонні, так і вітчизняні. Ними було сформульовано багато теорій, розроблено велику кількість класифікацій та схем.

Значний внесок у розвиток цього питання зробили такі вчені, як Л. П. Сміт, Х. Бредлі, Н. М. Морозова, які проаналізували словниковий запас англійської мови та виокремили певну структуру і схему самого процесу запозичення іншомовних слів. Розглянемо їх ідеї докладніше.

Багато вчень про англійську мову віддають значну частину іiі вокабуляру запозиченим словам, звертаючи таким чином увагу на періоди та види запозичень.

Запозичення - елемент чужої мови (слово, морфема, синтаксична конструкція та ін.), який було перенесено з одної мови до іншої в результаті мовних контактів, а також сам процес переходу елементів одної мови до іншої.

Зазвичай запозичуються слова, а рідше - синтаксичні та фразеологічні вирази. Запозичення окремих звуків та словотворчих морфем (суфіксів, префіксів, коренів) відбувається в процесі їхнього вторинного виділення 3 більшої кількості запозичених слів. Запозичення пристосовуються до системи мови-позичальниці, а іноді настільки нею засвоюються, що іншомовне походження таких слів не відчувається носіями мови та виявляється лише за допомогою етимологічного аналізу. Це стосується, наприклад, таких запозичень 3 тюркських мов (тюркізмів) як гарбуз, кавун, отара, козак.

На відміну від таких повністю засвоєних запозичень, так звані іноземні слова зберігають сліди свого іншомовного походження у вигляді звукових, орфографічних, граматичних та семантичних особливостей. Іноземні слова зазвичай належать до спеціальних галузей знань або виробництва (наприклад, ентомологія - наука про комах). Іноді вони позначають властиві чужим народам чи країнам поняття (етнографізми, регіоналізми, екзотизми) - наприклад, камамбер - сорт французького сиру. Такі слова тлумачаться словниками іншомовних слів або включаються до звичайних тлумачних словників.

Оскільки запозичення є результатом тривалої історичної взаємодії мов та їхнього змішування, то запозичення займають значне місце в ๑) В. В. Прима, 2012. 
лексиці багатьох мов. Підсилена взаємодія мов при зростаючій ролі культурних та економічних зв'язків між народами та країнами, а також при глобалізації, призводить до виникнення особливого шару запозичень, що номінуються інтернаціональними словами (інтернаціоналізмами). В українській мові прикладами таких слів є комітет, проект, інфляція та інші. У європейських мовах основний фонд інтернаціоналізмів складають слова, запозичені 3 грецької та латинської мов, на Близькому та Середньому Сході - слова з арабської та перської мов, на Далекому Сході - слова 3 китайської мови. Інтернаціональні слова часто належать до спеціальної термінології різних галузей знань, техніки та міжнародних відносин.

Канали запозичень можуть бути як усні (на слух), так і книжні (письмові) (за літерами). При усному запозиченні слово зазнає більше змін, аніж при книжковому запозиченні. Якщо слово входить до мови іншого народу з одночасним запозиченням нового предмета чи поняття, то значення цього слова не міняється; але у разі входження нового слова як синоніма до вже наявного в мові, між цими синонімами відбувається розмежування значень та спостерігаються зсуви в первісній семантиці. Такі запозичення іноді називають проникненнями.

Шляхи руху слова $з$ одної мови до іншої можугь бути прямими або непрямими. Українське слово кришталь запозичене з грецької мови

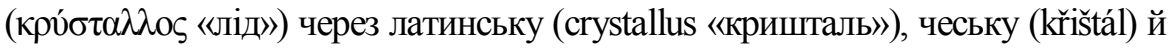
польську (krzysztal); а слово кристал також запозичене з грецької мови

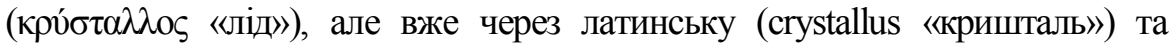
німецьку (Kristall) або французьку (cristal). Морфологічно складне запозичене слово у мові-позичальниці зазнає спрощення та сприймається як просте непохідне. Так, у слові магазин, яке прийшло до української мови через посередництво французької (magasin) з арабської (mahāzin «склади») вже не відчувається первісного значення множини та зв'язку 3 однокореневим йому арабським словом казна (арабське hazna «скарб, казна»), яке проникло до української мови через турецьку мову (hazna, hazne). (В арабській мові ці слова мають спільний корінь $h-z-n)$ [2, с. 34-78].

При масовому запозиченні іноземних слів зі спільними коренями та різними суфіксами або ж 3 різними коренями та спільними суфіксами ці словотворчі елементи можуть виділятися в мові, яка запозичує, та навіть утворювати нові слова. Так сталося, наприклад, з грецькими суфіксами -ist, -ism. 
Близько до запозичень стоять кальки (структурні запозичення), коли запозичена структура виражається питомим лексичним матеріалом. Поповнення словникового складу мови здійснюється різними засобами. Так, ними можуть бути запозичення з інших мов, розширення значень уже наявних слів. Усі ці засоби достатньо продуктивні.

Процес збагачення мови за рахунок раніш невідомих одиниць проходить постійно, освіжаючи та оновлюючи мову, приводячи іï у відповідність до потреб людей та змін, що постійно відбуваються у світі. Ось чому вивчення системи словотвору англійської мови, іiі компонентів, ступенів їх активності, продуктивності та варіативності $€$ таким необхідним.

До факторів, що впливають на виникнення нових одиниць (і на всю систему словотвору загалом), належать: екстралінгвістичні, науково-технічний та соціальний прогрес, поширення інформаційного потоку і необхідність передати його 3 найменшими витратами часу i місця, лінгвістичні фактори, тенденція до мовної економії, прагнення до аналітичності [8, с. 45-65].

Роль запозичень (borrowings, loan words) у різних мовах неоднакова і залежить від конкретно-історичних умов розвитку кожної. В англійській мові відсоток запозичень значно вищий ніж у багатьох інших: вона мала змогу запозичувати іншомовні слова в умовах прямого безпосереднього контакту: спочатку в середині сторіччя від загарбників, що змінювали один одного на Британських островах, а пізніше в умовах торгівельної експансії і колонізаторської активності самих англійців. Підраховано, що кількість власних слів в англійському словнику складає всього $30 \%$.

Не можна вважати, що роль слів у мові визначається тим, чи є воно запозиченим, чи власним. Тим паче, що найбільш уживані прийменники, сполучники, прислівники часу та місця, усі допоміжні і модальні слова, усі сильні дієслова і займенники, усі числівники, включаючи second, million, billion, є в сучасній англійській мові передвічними словами.

Той чи той вплив однієї мови на іншу завжди пояснюється історичними причинами: війни, завоювання, мандри, торгівля i т. ін., сприяли тісній взаємодії різних мов. Інтенсивність притоку нових запозичених слів у різні періоди не однакова. Залежно від конкретних історичних умов вона то збільшується, то падає. Ступінь впливу однієї мови на іншу при цьому залежить здебільшого від мовного фактора [7, с. 89-99].

Помилкові уявлення, які переважали в лінгвістиці щодо проблеми запозичень, не зводилися лише до перебільшення їх ролі в розвитку

๑) В. В. Прима, 2012. 
мови. Сам підхід до теми був одностороннім і формальним. Дослідників цікавили здебільшого джерела та дати утворення нових слів.

Треба приділяти увагу не тільки питанню, від кого запозичення, а й тому, що додалося та було створене в результаті діяльності при запозиченні слова від іншого народу. Необхідно творчо підходити до справи і тим самим створювати можливість виявити закономірності, яким підпорядковується розвиток словникового складу мови, пояснити явища, які відбуваються в ньому і виявити їх причини. Це можна пояснити прикладами.

Досліджуючи розвиток слова sport, ми не будемо зупинятися на тому, що це слово запозичене в середньо-англійський період із старофранцузької мови, де воно було desport і походило з латинської desportus. Desport та desportus значили відволікання, відхилення. При запозиченні відбулася спеціалізація значення і в середньо-англійській мові ці слова мали більш загальне значення, ніж у сучасній, де означає спорт, розвагу. 3 цим словом у той же період із французької мови в англійську запозичувалися інші слова, які були пов'язані з розвагами заможних людей. Це пояснюється тим, що в XI столітті нормандські барони стали власниками країни. Англосаксонська верхівка завоювала їх звичаї і нормандський діалект старофранцузької мови. Слово sport підкорюється англійській системі граматичних змін іменників, отримуючи можливість в множині закінчення s. У ньому не тільки замінюються всі звуки англійськими, але й відпадає перший склад (аферезис). У новоанглійській мові це слово має ще деякі зміни в семантиці й означає фізичні вправи, у вигляді ігор та змагань. У словниковому складі англійської мови паралельно зберігається дієслово disport розважатися, яке називається маловживаним [6, с. 113-119].

Зараз в сучасну англійську мову були запозичені слова з різних мов, які зберегли своє значення. Наприклад, aiki-jutsu, boutique, kelim, kletten prinrip. Ці слова здебільшого мають теж значення, яке вони мали в похідній мові, але деякі з них розширюють значення.

Отже, ніяке нове поповнення словника запозиченнями не може минути безслідно для лексичного складу. Запозичене слово приймає на себе одне або кілька значень семантично близьких до нього слів, що вже раніше існували в мові.

Узаємодію запозичень і словникового складу мови, що їх прийняла, добре видно з історії слів, які означають поняття працювати іє синонімами до слова work. Після запозичення в середньо-англійський період дієслів: 
labouren «працювати» (із ст.-фр. labourer, лат. laborare) i travaillen «важко працювати» (із ст.-фр. travaillen, нор. лат. trepaliare «мучити»), перше з цих дієслів близько до англійського swincan. Друге дієслово travailler не витримало конкуренції з дієсловом werken і має значні зміни у змістовій структурі. Після цього його основне значення «мандрувати» to travel.

Деякі зміни проходять із словами, які були запозичені 3 французької мови. Слово extheticienne було запозичене англійською мовою, де зберегло своє значення, але змінило вимову аestheticlenne.

\section{Література}

1. Авронин В. А. Проблемы изучения функциональной стороны язика / В. А. Авронин. - Л., 1975.

2. Адмони В. Г. Структура предложения и словосочетания в индоевропейских язиках / В. Г. Адмони. - Л., 1979.

3. Азар В. Туризм - еще один феномен XX века / В. Азар // Туризм: практика, проблемы, перспективы. - № 5. - 2003. - С. 15-17.

4. Барт Р. Воображение знака / Р. Барт // Избр. работы: Семиотика. Поэтика. - М. : Прогресс, 1989. - С. 246-252.

5. Кабакчи В. В. Англоязычное описание русской культуры / В. В. Кабакчи. M. : Academia, 2009. -224 c.

6. Смирницкий А. И. Лексикология английского языка / А. И. Смирницкий. М. : Изд-во лит-ры на иностран. языках, 1956. - 260 с.

7. Krilova I. P. A Grammar of Present-Day English / I. P. Krilova. - M., 1974. - p.16

8. Kuznetsova V. Notes on English Lexikology / V. Kuznetsova. - K. : Радянська школа, 1966.

Стаття надійшла до редакції 15.11.2012 p. 